\title{
LA RETÓRICA DISCURSIVA DE FRANKLIN D. ROOSEVELT EN LA CAMPAÑA ELECTORAL DE 1932
}

\author{
ANTONIA SAGREdo SANTOS \\ UNED \\ asagredo@flog.uned.es
}

\section{RESUMEN}

En este artículo se analiza el impacto que tiene la figura de Franklin D. Roosevelt en la campaña electoral estadounidense de 1932 así como el lenguaje que utiliza para presentar a los norteamericanos la crisis económica que se vivía en ese momento en el país. Asimismo, se va a centrar en algunos de sus discursos más significativos y cómo en ellos se van a ir anunciando las principales líneas políticas que Roosevelt pondrá en práctica cuando llegue a la Casa Blanca el 4 de marzo de 1933. El conjunto de medidas legislativas que propone el presidente y aprueba el Congreso para mitigar los efectos de la Gran Depresión en los Estados Únidos son conocidas bajo el nombre genérico de New Deal.

Palabras Clave: Estados Unidos, Franklin D. Roosevelt, Campaña electoral de 1932, New Deal, Discursos.

\section{ABSTRACT}

This article analyses the impact that the figure of Franklin D. Roosevelt had on the 1932 Electoral Campaign and the language he used in his political speeches to make the American people aware of the economic crisis they were going through. This essay also focus on some of the most relevant addresses and how they were going to introduce the main policies that Roosevelt was going to put into practise when he reached the 
White House on March 4, 1933. The whole legislative measures which the president promoted and the Congress passed to mitigate the Great Depression effects in the United States were known under the generic name of New Deal.

Key Words: United States, F. D. Roosevelt, 1932 Electoral Campaign, New Deal, Addresses.

\section{INTRODUCCIÓN}

Las elecciones presidenciales estadounidenses de noviembre de 1932 van a ser seguidas con gran interés por todo el mundo occidental que está pendiente de las medidas que se van a promover en los Estados Unidos para salir de la profunda crisis económica en que está sumido todo el sistema capitalista desde que se registró el crack en la Bolsa de Nueva York el 29 de octubre de 1929, conocido como Black Tuesday. Las soluciones que propongan los Estados Unidos para salir de la depresión van a depender, en gran medida, de la política que desarrolle el candidato que alcance la Casa Blanca, como reconoce Nicholas Halasz (1961: 24): «America, the strongest representative of the system, was called upon to demonstrate its ability to recover and its capacity for self-help. From the success of the strong, the weaker ones would draw hope and strength».

A las elecciones norteamericanas de 1932, van a acudir los dos grandes partidos, el republicano y el demócrata. Además están los «terceros partidos». El más representativo es el socialista, cuyo candidato a la presidencia es Norman Thomas, periodista y pastor protestante, quien está apoyado por grupos políticos de izquierda y la facción disidente del partido comunista. El partido comunista también participa en estas elecciones, aunque en Estados Unidos tiene poca fuerza política. Su candidato a la presidencia es William Foster. Sin embargo, debido, principalmente al descontento de los trabajadores y al rechazo existente hacia los dos grandes partidos, crece el movimiento del tercer partido en Estados Unidos en 1932, aunque no incrementa el número de votos como aseguran Peel y Donnelly (1973: 222): «the third parties did not fare very well in any state».

Tres días antes de las elecciones americanas, la publicación británica The New Statesman and Nation describe de forma realista las escasas posibilidades del socialista Norman Thomas de llegar a la presidencia ya que el deseo de derrotar a Mr. Hoover es tan grande que es muy probable que la gente que, de otro modo hubiera elegido a Mr. Thomas, votará a Mr. Roosevelt por miedo a malgastar su voto. El periódico del partido laborista británico, Daily Herald, explica esta ausencia de apoyo en las urnas en los siguientes términos: «reason is practically non-existent in American political elections, and the workers are unorganized"1.

Al partido republicano, que se encuentra en el poder en 1932, habiendo ocupado la presidencia durante la década de los 20, se le relacionaba con el supuesto auge económico, como manifiesta el historiador Harold F. Gosnell (1952: 123): «the electorate had associated the Republican candidates with the economic well-being of the country.»

${ }^{1}$ The New Statesman and Nation, 5-11-1932, p. 538. Daily Herald, London, 24-5-1932. Cf. John Dizikes (1979: 27). 
No es así extraño que cuando Herbert C. Hoover llega a la Casa Blanca en 1928, el eslogan de su campaña sea «¿Por qué cambiar?». Durante su mandato se desencadena la crisis económica y su gestión ante la misma es criticada incluso por miembros de su propio partido, provocando que algunos de ellos se pasen a apoyar al candidato demócrata² A pesar de esta oposición, Hoover es elegido de nuevo candidato republicano en 1932, en la Republican National Convention que tiene lugar del 14 al 17 de junio en Chicago, y pronuncia su discurso de aceptación el 11 de agosto.

Los republicanos acuden a las elecciones de noviembre de 1932 con un cierto aire de derrota, facilitando el camino al candidato demócrata. Esta premonición de fracaso que existe en las filas republicanas es recogida por la historiografía posterior, que frecuentemente subraya este aspecto del proceso electoral de $1932^{3}$. Por su parte, el partido demócrata, a pesar de haber estado alejado del poder durante toda la década de los 20 , acude a las elecciones de 1932 con gran esperanza y confiado de que la victoria será suya: «the Democratic party oponed the 1932 campaign confident of victory» (Leuchtenburg, 1963: 1).

\section{La PeRsonalidad de Franklin D. RoOseVelt en la CAMPaña EleCtoral}

La campaña electoral de 1932 se centra, pues, en la lucha de dos hombres por llegar a la presidencia del país: Herbert C. Hoover y Franklin D. Roosevelt. El historiador liberal, William E. Leuchtenburg afirma que en esta campaña se observan posturas muy diferentes en los dos candidatos:

If Roosevelt's program lacked substance, his blithe spirit, his infectious smile, his warm, mellow voice, his obvious ease with crowds contrasted sharply with Hoover's glumness. While Roosevelt reflected the joy of a campaigner winging to victory, Hoover projected defeat» (1963: 13).

Igualmente, otro historiador liberal, Harold F. Gosnell, escribe:

In spite of his physical handicap, FDR was buoyant, joyous, confident, calm, courageous, and charming, while the adversity that had been heaped on Hoover's head since 1929 made him depressed, sour, timid, uncertain, and distant in his social relationships (1952: 124).

${ }^{2}$ El historiador conservador Edgar E. Robinson (1970: 32) describe el trasvase de personajes ilustres de las filas republicanas a las demócratas: «Prominent Republicans had disagreed with Mr. Hoover throughout his administration. Several Republicans of national reputation vigorously supported the candidacy of Mr. Roosevelt». En la prensa española aparece reflejado este hecho, véase por ejemplo: «La candidatura de Roosevelt es apoyada por un buen número de senadores republicanos: los llamados independientes». En: «Las elecciones en los EE. UU.- Programas de los partidos», La Vanguardia, Barcelona, 8-11-1932, p. 28. «Parece que elementos significativos conservadores apoyan a Roosevelt». En: «En vísperas de las elecciones presidenciales en los Estados Unidos», El Liberal, Sevilla, 9-11-1932, p. 5.

${ }^{3}$ Por su parte, el historiador Michael Simpson (1989: 18) afirma: «the Republicans' failure to cure the Depression virtually guaranteed a Democratic victory». Sean J. Savage (1991: 103) destaca: «the anti-Hoover sentiment that emerged after 1929 would assure the victory of almost any Democratic presidential nominee in 1932». Russell D. Buhite y David W. Levy, eds. (1993: 9) destacan la misma idea: «Hoover's unpopularity would assure the presidency to whomever the Democrats nominated». 
La personalidad del candidato demócrata, Franklin D. Roosevelt, es fundamental en estas elecciones, ya que tiene una gran facilidad para comunicarse con las personas. Nicolas Halasz en su obra Roosevelt Through Foreign Eyes mantiene: «the agility of his speech is remarkable. Memories and anecdotes come crowding into his mind» (25). El estudioso británico, John Dizikes (1979: 27), por su parte, describe la atracción que ejerce Roosevelt: «he spoke effectively in public, his speeches were of unexpectedly high quality, and the crowds coming to see and hear him were growing noticeably in size and enthusiasm.» La prensa liberal española refleja esta misma valoración asegurando que «el americano medio comprende a Mr. Roosevelt mucho mejor que a Mr. Hoover"4.

Los titulares de toda la prensa española de izquierda destacan la oratoria del candidato demócrata: «su voz grave suena agradablemente en el oído... su dicción es clara y distinta... es un buen orador"5. En La Libertad se lee: «Roosevelt es el tipo del realismo sincero y real». El Sol afirma: «el uno es todo sonrisa: Franklin Roosevelt. El otro frunce el entrecejo: Herbert Hoover». También, en el diario La Voz de Galicia se analiza la personalidad de Roosevelt, contraponiéndola a la de Hoover, observándose una gran muestra de afecto por el representante demócrata: «Roosevelt muy superior en simpatía, en ardor polémico y en atractivo personal al duro Hoover, personificación del talento organizador, sin gracia y sin efusión cordial». Asimismo, La Vanguardia, destaca las dotes de buen comunicador del candidato demócrata: «[Roosevelt] sabe llegar, con su oratoria clara, de vivas imágenes, hasta el fondo de la sensibilidad del elector de tipo medio"6.

Roosevelt también tiene sus detractores, quienes no lo consideran idóneo para ocupar la presidencia. Especialmente, en la prensa del este de los Estados Unidos, se le presenta como un hombre sin convicciones e incapaz de realizar acciones decisivas. Entre sus principales críticos, se puede citar al editor y periodista Walter Lippman, quien lo ataca diciendo: «he is a pleasant man who, without any important qualifications for the office, would very much like to be President» (Cf. Steel, 1980: 287). Igualmente, Elmer Davis piensa que los demócratas han elegido «the man who would probable make the weakest President of the dozen aspirants». Charles Willis Thompson, un veterano corresponsal en Washington, afirma: «the Democrats have nominated nobody quite like him since Franklin Pierce..."ๆ. El columnista liberal, Heywood Broun, le califica despectivamente como: «the cork-screw candidate» (Cf. Freidel, 1987: 5).

4 «La gran batalla por la presidencia de los Estados Unidos.- El carácter, los títulos, las cualidades y el exterior de los candidatos a la Casa Blanca», El Sol, Madrid, 22-10-1932, p. 1.

5 «Las elecciones presidenciales en los Estados Unidos.- El Vencedor...», El Liberal, Madrid, 9-11-1932, p. 9. En este artículo se utiliza la palabra «distinta» en castellano, que sin duda es una traducción poco acertada de distinct en inglés, con el significado de claro y bien enunciado.

6 «Las elecciones en Norteamérica.- El triunfo de Roosevelt», La Libertad, Madrid, 19-11-1932, p. 3. «La gran batalla por la presidencia de los Estados Unidos.- El carácter, los títulos, las cualidades y el exterior de los candidatos a la Casa Blanca», El Sol, Madrid, 22-10-1932, p. 1. Dámaso Calvo. «Franklin D. Roosevelt», $L a$ Voz de Galicia, La Coruña, 8-3-1933, p. 1. «Roosevelt y Hoover», La Vanguardia, Barcelona, 12-11-1932, p. 5 .

7 Elmer Davis, «The Collapse of Politics». Harper's CLXV, (1932), p. 388. Charles W. Thompson. «Wanted: Political Courage». Harper's CLXV, (1932), pp. 726-727. Cf. William E. Leuchtenburg (1963: 9-10). 


\section{La Candidatura de F. D. RoOSEVelt Y SU Discurso de ACEPTACión}

Antes de su elección como candidato demócrata, Franklin D. Roosevelt pronuncia dos importantes discursos. El primero de ellos se inspira en el tema del Forgotten Man, una de las frases de Roosevelt más recordadas ${ }^{8}$. Lo difunde por radio el 7 de abril de 1932, desde Albany, Nueva York, donde desempeña el cargo de gobernador del Estado. En él promete solucionar la crisis económica, que afectaba a todos los sectores económicos del país, haciéndolo desde abajo a arriba y no desde arriba abajo, para tratar de remediar la trágica situación de las capas más desfavorecidas de la sociedad norteamericana:

These unhappy times call for the building of plans that rest upon the forgotten, the unorganized but indispensable units of economic power, for plans like those of 1917 that build from the bottom up and not from the top down, that put their faith once more in the forgotten man at the bottom of the economic pyramid (Cf. Burns, 1984: 133).

Este discurso fue escrito por Raymond Moley, un profesor de la universidad de Columbia y miembro del Brain Trust ${ }^{9}$. En él se acusa al presidente republicano Herbert C. Hoover y a su administración de haber fallado en la lucha contra la grave depresión por haber tenido en cuenta solamente: «the top of the social and economic structure» (Cf. Simpson, 1989: 20). Este discurso intensificó la oposición hacia su candidatura de los sectores más conservadores de la política norteamericana, «in the highly charged atmosphere of the depresión, many conservatives interpreted Roosevelt's referente to the «forgotten man» as an incitement to class conflict» (Maney, 1992: 37). Igualmente, el periódico español $L u z$ se hace eco de este discurso: «... y mira solamente los intereses del «ciudadano olvidado», como él mismo ha calificado al hombre medio que trabaja y es víctima de las presentes circunstancias económicas" ${ }^{\prime 10}$.

El voto de ese forgotten man, a quien va dirigido su mensaje, es el que le lleva a la presidencia de los Estados Unidos, como nos presenta Nicholas Halasz:

The army of ten million unemployed, the three million more men and women who may be out of jobs this winter, the hundreds of thousands who have seen their capital savings disappear into the thin air. From them came Roosevelt's huge majority. Their disillusionment, their despair accrued to him. He was elected by the forgotten man, to whom he had promised to lead the United States back onto the road of clear reason (1961: 23).

${ }^{8}$ Raymond Moley, asesor de Roosevelt para temas económicos, es el autor de este discurso y toma el título del famoso ensayo de William Graham Sumner, «The Forgotten Man», aunque Sumner se refiere a los trabajadores en general, Moley aplica el término a todos los afectados por la depresión. Cf. Halford R. Ryan (1988: 40-41).

9 Eleanor Roosevelt, esposa del candidato demócrata y su más cercana colaboradora, en su libro autobiográfico This I Remember (1949: 66-67) nos presenta al Brain Trust: «The men who formed the so-called Brain Trust were picked chiefly by Louis Howe and Sam Rosenman. They were a group with whom Franklin consulted in laying plans to meet the problems that all of us were aware had to be met by whoever was elected president in 1932. There were laywers, professors, politicians, all gathered together to think out ways and means of doing specific things. The original «brain trust» consisted of Professor Raymond Moley, Professor Rexford G. Tuxwell, and Judge Samuel I Rosenman. Later Adolf Berle was brought in, and on certain occasions Dr. Joseph McGoldrick and General Hugh Johnson were consulted».

10 J. M. Escuder. «Cartas de Nueva York.- El futuro de Mr. Roosevelt», Luz, Madrid, 26-11-1932, p. 5. 
El segundo discurso lo pronuncia en la Universidad Oglethorpe en Atlanta, Georgia, el día 22 de Mayo de 1932. En él, Roosevelt alude a la necesidad de redistribuir la renta nacional, y de planificar y experimentar, aunque sin mencionar las medidas concretas que aplicaría. En este discurso, el candidato demócrata emplea un lenguaje duro y directo, responsabilizando a los bancos de la situación critica por la que pasa la economía estadounidense, como se desprende de los escritos de Rexford G. Tugwell (1968: 112), miembro del Brain Trust, quien afirma: «the whole speech was taken to be an attack on «selfish and opportunist» groups, and these were the bankers».

El 27 de junio de 1932 se reúne en Chicago la Democratic National Convention considerada como «a six-day battle» (King 1959: 258). Franklin D. Roosevelt, elegido en 1928 gobernador del estado de Nueva York y reelegido de nuevo en 1930, se perfila como futuro candidato presidencial. Tiene la mayoría de los votos de los delegados pero aún le quedan por conseguir cien votos más para completar los dos tercios necesarios para poder ser proclamado candidato demócrata. En las tres primeras votaciones, Roosevelt solamente consigue un escaso incremento de votos a su favor.

El 1 de julio se realiza la cuarta y definitiva votación. Antes de que esta se produjera se realiza una maniobra política de gran calado y Roosevelt anuncia que elige a John N. Garner de Texas para acompañarle en la futura campaña presidencial. A continuación, William Gibbs McAdoo anuncia que el estado de California cambia su voto, que anteriormente había sido para John N. Garner, a Franklin D. Roosevelt: «to bring this contest to a swift end and, we hope, satisfactory conclusion... Garner had told his Texas delegates to follow suit» (King 1959: 258). A partir de este hecho los votos de varios estados son para Roosevelt, superando los dos tercios que le convierten en el candidato demócrata a las elecciones de 1932. Russell D. Buhite y David W. Levy (1993: 9) describen el camino de Roosevelt hacia la victoria con estas palabras: «Roosevelt emerged victorious from the Chicago convention of 1932 and set out to convince Americans to vote for him in November». Asimismo, el historiador británico John Dizikes mantiene que:

The figure of Franklin Roosevelt thrown up by circumstances from out the bewildering flux of American politics, rose suddenly into view; then, gaining in public estimation, displacing men who had been better known, swept through the presidential primaries and move from relative obscurity at one moment, to importance the next, this tribe of supporters irresistibly increasing, until, at Chicago, his name led all the rest» (1979: 24).

El candidato demócrata permanece en Albany durante las votaciones y ante el asombro de todos los asistentes, dando un gran golpe de efecto, vuela a Chicago y se presenta ante la Convención el día 2 de julio para aceptar personalmente su nombramiento, rompiendo con la tradición que hacía que el candidato presidencial no estuviera presente en la convención de su partido, como nos describe con gran detalle su esposa Eleonor Roosevelt en su libro This I Remember:

The plane trip was something no candidate had ever before undertaken and it created considerable excitement. Previously, the candidate had not been officially notified of his nomination until later in the summer, which meant long trips for the members of the notification com- 
mittee. Franklin though that in times as serious as those of 1932 this was an unnecessary expense. Louis Howe met us when we arrived in Chicago and we proceeded though crowded streets and cheering crowds to Convention Hall (1949: 70-71).

Hasta ese momento, había unas semanas de diferencia entre el día de la elección del candidato y la notificación oficial del nombramiento al mismo por lo que no existía la costumbre de que el elegido pronunciara un discurso de aceptación. Así, Roosevelt presenta un discurso para aceptar su nominación que concluye con las dos palabras históricas «New Deal» que van a ser emblemáticas de su política:

I pledge you, I pledge myself, to a «NEW DEAL» for the American people. Let us all here assembled constitute ourselves prophets of a new order of competence and of courage. This is more than a political campaign; it is a call to arms. Give me your help, not to win votes alone, but to win in this crusade to restore America to its own people ${ }^{11}$.

El nombramiento de Franklin D. Roosevelt como candidato demócrata es considerado por Judson King (1959: 260) como «a pivotal moment in American history». Numerosos observadores afirman, cuando Roosevelt es nombrado candidato demócrata, que será el vencedor en las elecciones de noviembre ${ }^{12}$. Se puede decir que en 1932, la sociedad norteamericana vive una situación caótica y los Estados Unidos tienen necesidad de un tónico. Roosevelt sabe ganarse la voluntad de la mayoría del pueblo americano y dar ánimo a sus compatriotas, transmitiéndolos la idea de que la humanidad aún puede dirigir su propio destino ${ }^{13}$. El nuevo Presidente personifica «the desire for a change and the hope of recovery» (Bourne \& Watt, 1986: 290). Como expresa el historiador liberal Frank Freidel (1987: 1), «he began by living the nation firm, optimistic leadership at the nadir of the depression crisis».

\section{PRincipales disCuRSOS DE LA CAMPAÑA EleCtORAL DE 1932}

En la campaña de 1932, Roosevelt va a presentar su programa electoral por todo el país, recorriendo treinta y dos estados y 13.000 millas en ocho semanas. Samuel I. Rosenman, uno de sus asesores, manifiesta que: «by October it was more like a triumphal tour than a campaign for Roosevelt» (1952: 89). Roosevlt pronunciría dieciséis importantes discursos y sesenta y siete discursos menores. El candidato demócrata está rodeado de un equipo de asesores, conocido como el Brain Trust. Este grupo es el principal responsable de la elaboración de sus discursos, como escribe Edward J. Flynn, quien trabajó en la campaña electoral demócrata de 1932:

${ }^{11}$ Franklin D. Roosevelt. «Speech Before the 1932 Democratic National Convention». Acceptance Speech. Chicago, Illinois, July 2, 1932. En: John G. Hunt, ed. (1996: 17-29).

12 John McCooey, «The Boss of Brooklyn», afirma después de la Convención Demócrata: «Roosevelt would be the next President without campaigning.» Cf. Harold F. Gosnell (1952: 132). John Dizikes (1979: 25) mantiene que la opinión pública británica no confiaba tanto en el triunfo de Roosevelt: «as the campaign began, British observers believed that Roosevelt would win, but that the result would be very close».

13 «Humanity still possesses some power of directing its own destinies». The Spectator, (December 20, 1932), p. 906. 
His so-called «brain trust» had been organized in March, and with their assistance he had planned his whole strategy as far as speeches were concerned. Many of them were already written. About the only decision he had left to make was where certain types of speeches were to be delivered (1947: 118).

Sin embargo, Michael Simpson (1989: 19) afirma que Roosevelt siempre introduce en ellos su toque personal: «most of his major statements in 1932 reflected Brains Trust advice, but he was never the prisoner of any group».

El 14 de septiembre de 1932, el candidato electo Franklin D. Roosevelt pronuncia en la ciudad de Topeka, Kansas, un discurso que es el más claro llamamiento al voto campesino de toda la campaña. Es un discurso muy elaborado. Raymond Moley, asesor económico de Roosevelt, cuenta que trabajaron en su redacción veinticinco personas ${ }^{14}$. En esta ocasión propone medidas concretas para solucionar el problema del campo:

On my part, I suggest the following permanent measures: first, I would reorganize the Department of Agriculture, and I would do it with the purpose of building up a program of national planning... Second, I favor a definite policy looking forward the planned use of the land... A third process of permanent relief of agriculture will come in the reduction and more equitable distribution of taxes... It is necessary to adopt quick-acting remedies. In the first place, there is the necessity, as we all know, for the better financing of farm mortgages... (and) a substantial reduction in the difference between the prices of things the farmer sell and the things the farmer buys ${ }^{15}$.

El historiador liberal, William E. Leuchtenburg (1963: 10), manifiesta que el candidato demócrata no se expresa claramente en el discurso que pronuncia en Topeka y mantiene que «this Topeka speech left the leaders, as it was to leave historians, arguing over precisely what he intended. He would initiate a far-reaching plan to help the farmer; but he would do it in such a fashion that it would not «cost the Government any money». Por su parte, Sean J. Savage considera que es necesario un cierto grado de ambigüedad en las afirmaciones de Roosevelt en Topeka, debido a la gran diversidad ideológica que existía entre los demócratas de los estados del sur y los del este que apoyan su candidatura, como se lee en las siguientes líneas:

His coalition included segregationist southern conservatives... as well as maverick, trustbusting western populists... Ideologically, though, the southern conservatives and western populists had in common a contradictory desire to solve the agricultural problems of their states through federal action while avoiding a greater centralization of power in Washington (1991: 104-105).

Sin embargo, Harold F. Gosnell (1952: 130) considera que: «it was satisfactory to the leaders of the farm organizations and that it therefore anticipated the agricultural mea-

${ }^{14}$ Raymond Moley (1939: 45) describe fielmente en esta obra autobiográfica el proceso de elaboración de algunos de los discursos de campaña de Franklin D. Roosevelt. Asimismo, Moley marca su ruptura con el New Deal en esta obra.

15 Este discurso de Topeka aparece recogido en un folleto que se distribuyó por el agro estadounidense para que llegaran al farmer norteamericano las propuestas agrarias del candidato demócrata. Governor Franklin D. Roosevelt. Agriculture. What Is Wrong and What To Do About It? Speech at Topeka, Kansas, September 14, 1932, pp. 8-10. 
sures which were to become such a storm center later... A rereading of the speech today shows that it was prophetic in many aspects».

En las elecciones de 1932, el partido demócrata va a obtener más votos que los republicanos en los counties agrarios debido a la oposición del agro americano hacia la política de Hoover. Como asegura Daniel R. Fusfeld (1987: 139), muchos agricultores están dispuestos a hacer un cambio político hacia el partido demócrata. Los farmers forman un colectivo muy importante y decisivo para que llegue Roosevelt a la Casa Blanca. El mundo agrario está dispuesto a dar su voto a aquel candidato que defienda mejor su causa que, en este caso, parece que coincide con el demócrata, «there is no man in public life who is more thoroughly conversant with the needs of the farmer than Franklin D. Roosevelt... and the only proof needed of such a statement is a brief study of his life's background» ${ }^{16}$. En esta misma línea el diario español El Liberal de Madrid expone: «Roosevelt es el orador de la América rural, del «hombre olvidado en los solitarios campos»... defiende la causa... del agricultor ahogado" 17 .

En Portland, Oregon, el 21 de septiembre, Roosevelt propugna la intervención gubernamental en las empresas de servicios públicos, punto sobre el que discrepan los republicanos. Dos días más tarde habla en el Commonwealth Club de San Francisco, California. Este discurso está dirigido a los hombres de negocios. El historiador Harold F. Gosnell lo considera como uno de los más importantes de toda su campaña pues resume la filosofía del New Deal. Roosevelt proclama en él, con gran claridad, la función intervencionista del gobierno ${ }^{18}$.

El discurso pronunciado por el candidato demócrata en la ciudad de Detroit, Michigan, el 2 de octubre de 1932, está dirigido al mundo de la industria norteamericana y trata sobre justicia social. En él propone que las ayudas a los necesitados procedan tanto de los estados como del gobierno federal. En este discurso Roosevelt cita un pasaje de la Encíclica Pontificia de Pío XI Quadragessimo Anno:

... this concentration of power has led to a three-fold struggle for domination: First, there is the struggle for dictatorship in the economic sphere itself; then the fierce battle to acquire control of the Government, so that its resources and authority may be abused in the economic struggle, and, finally, the clash between the Governments themselves ${ }^{19}$.

Roosevelt finaliza el discurso de Detroit con unas palabras en las que hace referencia a la justicia social:

${ }^{16}$ En la prensa norteamericana se trata ampliamente la relación de Roosevelt con el mundo agrario. A título de ejemplo se han citado unas líneas incluidas en: «Franklin D. Roosevelt Knows Needs of Farmers and Breeders». The Breeders' World VII/9, (September 1932), p. 15. También se destaca en la historiografía posterior el interés que demuestra Roosevelt por mejorar la situación de la agricultura durante sus años como gobernador del estado de Nueva York. Véase por ejemplo Sean J. Savage (1991: 104).

17 «Las elecciones presidenciales en los Estados Unidos.- El vencedor...», El Liberal, Madrid, 9-11-1932, p. 9.

18 Adolph Berle es el autor de este discurso y lo revisa el Brain Trust. El título que le da Berle es «Progressive Government», que describe perfectamente el contenido del discurso. En Halford R. Ryan (1988: 43).

${ }^{19}$ La Carta Encíclica «Quadragesimo Anno» fue promulgada el 15 de mayo de 1931 por S.S. Pío XI, sobre la restauración del orden social en perfecta conformidad con la ley evangélica al celebrarse el $40^{\circ}$ aniversario de la encíclica «Rerum Novarum» de León XIII, a lo que debe su nombre. Véase Franklin D. Roosevelt. Campaign Address, Detroit, Michigan, October 2, 1932. Cf. Edwin C. Rozwenc, ed. (1959: 51). 
And so, in these days of difficulty, we Americans everywhere must and shall choose the path of social justice, the only path that will lead us to a permanent bettering of our civilization, the path that our children must tread and their children must tread, the path of faith, the path of hope and the path of love toward our fellow man (51).

El 19 de octubre, Roosevelt pronuncia un discurso en la ciudad de Pittsburg sobre política económica. En él promete reducir los gastos del gobierno un $25 \%$, aunque al no poder cumplirlo durante su mandato, esta promesa va a ser utilizada en su contra en el futuro y como mantiene Harold F. Gosnell (1952: 129): «it was to plague him most in after years».

El candidato demócrata pronuncia un discurso en la ciudad de Nueva York, el día 4 de noviembre de 1932 donde pasa revista a los principales puntos contenidos en los principales discursos de su campaña ${ }^{20}$. Al completar Franklin D. Roosevelt su gira por el oeste $^{21}$ y tras su vuelta a la ciudad de Nueva York, el diplomático británico D. G. Osborne, destinado en los Estados Unidos, envía sus impresiones sobre este viaje al Foreign Office británico destacando que Roosevelt ha obtenido un gran éxito personal y político y se ha asegurado, en gran medida, el apoyo del sector progresista del país:

Governor Roosevelt has now completed his Western tour and returned to Albany. He has good reason to be content, for there is no doubt that it was both a personal and a political success, and, incidentally, he has completely disposed of any legend of ill-health or lack of stamina... He has secured the endorsement of a considerable proportion of the progressive element in the country, his personality, principles and policies have had a wide appeal... ${ }^{22}$

La campaña electoral norteamericana de 1932 va tocando a su fin y el candidato demócrata pronuncia el último discurso de su campaña en Poughkeepsie, localidad cercana a su residencia familiar de Hyde Park, en el estado de Nueva York, la tarde anterior a las elecciones. Por su parte, Hoover termina su campaña en el oeste y acude a votar a Palo Alto, California ${ }^{23}$.

Algunos escritores liberales como Samuel I. Rosenman (1952) o Arthur M. Schlesinger (1957), insisten en que Roosevelt predice lo que va a ser el «New Deal» durante su campaña electoral. Sin embargo, el conservador Halford R. Ryan (1988: 39), afirma que Roosevelt basa su campaña en atacar a la política del partido republicano en el poder, con acusaciones concretas, sin presentar su visión política, y aludiendo solamente a generalidades sin aportar soluciones concretas.

${ }^{20}$ Franklin D. Roosevelt Speech. New York City, Nov. 4, 1932. Governor Roosevelt's Public Papers 1932 (1939: 664).

21 Algunos de los asesores de Franklin D. Roosevelt se oponen a su viaje a California. Consideran que el riesgo es demasiado grande porque California es un territorio peligroso, ya que allí el partido demócrata está muy fraccionado. Véase Harold F. Gosnell (1952: 125-126).

${ }^{22}$ Carta de D. G. Osborne a Sir John Simon. En: Kenneth Bourne \& D. Cameron Watt, eds. (1986, II: 292293).

${ }^{23}$ Edward J. Flynn (1947: 122), relata el último acto electoral de Roosevelt. El final de la campaña electoral, de los dos principales partidos, se refleja ampliamente en la prensa española coetánea. Véase por ejemplo: «Ante las próximas elecciones presidenciales. Los candidatos Roosevelt y Hoover se disponen a terminar su campaña electoral», Ahora, Madrid, 6-11-1932, p. 11. «Hoover y Roosevelt se aprestan a la lucha», La Libertad, Madrid, 6-11-1932, p. 3. «Hoy celebran los candidatos Hoover y Roosevelt los últimos actos políticos», Heraldo de Madrid, Madrid, 7-11-1932, p. 11. «... El último discurso», El Debate, Madrid, 9-11-1932, p. 1. 


\section{El triUnfo de Franklin D. RoOSEVelt y SU DisCURSO INAUGURAL}

En las elecciones de 1932, se emiten 39.732.000 votos. El candidato demócrata, Franklin D. Roosevelt, consigue 22.810 .000 y el triunfo en 42 estados, mientras que el candidato republicano, Herbert C. Hoover, obtiene 15.759 .000 y gana en seis estados ${ }^{24}$. En el electoral college el ganador recibe 472 votos y el candidato republicano 59. Hay una ostensible diferencia de votos a favor de Roosevelt.

En la historiografía posterior se destaca el rechazo del pueblo americano hacia la política del republicano Herbert C. Hoover considerándolo factor determinante en el resultado de estas votaciones. El historiador liberal, Frank Freidel (1987: 5) destaca: «they voted against Hoover rather than positively for Roosevelt». Siguiendo este argumento, William E. Leuchtenburg (1988: 38) recalca: «yet this heady triumph, reflec[ted] resentment at Hoover more than approval for FDR and the Democrats...». Igualmente, Nicholas Halasz (1961: 23) afirma: «his election was a demonstration of anger and disillusionment».

Franklin D. Roosevelt es consciente del importante papel que debe desempeñar la presidencia en la reconstrucción del país. Cuando le preguntan si pasará a la historia como el mejor presidente norteamericano si tiene éxito y como el peor si fracasa, Roosevelt contesta que si falla, será el último (Cf. Peel \& Donnelly, 1973: 213).

Arthur M. Schlesinger, Jr. (1974: xx) señala que a pesar de que Andrew Jackson revoluciona la presidencia, los precedentes que crea no son utilizados de forma sistemática por ningún sucesor en períodos de paz hasta que lo hace Roosevelt. Éste impone una nueva forma de desempeñar la presidencia y su estilo es tomado como ejemplo por los sucesivos primeros mandatarios de los Estados Unidos. William E. Leuchtenburg (1983: x), analizando la influencia de Roosevelt sobre los mandatos de sus sucesores, afirma: «cada uno espera tener una rúbrica, ser conocido por tres iniciales como FDR, ser el progenitor de una catch phrase como New Deal... Los hombres que le sucedieron se hacen una pregunta inevitable: ¿Cómo estar a la altura de FDR?». Esta influencia llega hasta el momento actual como recoge el diario madrileño El País en sus titulares: «Clinton se apega a la memoria de Roosevelt para defender su política ${ }^{25}$. Franklin D. Roosevelt se ve a sí mismo como el sucesor de Theodore Roosevelt y Woodrow Wilson en la Progressive and Liberal Tradition. Entre los diarios de izquierda españoles se destaca la llegada de un liberal a la presidencia: «Roosevelt quiere ser considerado como un liberal... ${ }^{26}$. Asimismo, la prensa española se hace eco de la favorable acogida del triunfo de Roosevelt en la prensa neoyorquina ${ }^{27}$.

Desde la celebración de las elecciones, el 8 de noviembre de 1932, en que Franklin D. Roosevelt alcanza la presidencia del país, hasta su toma de posesión el 4 de marzo de

${ }^{24}$ Los resultados de las elecciones americanas, incluida la de 1932, se estudian comparativamente en el artículo de David C. Nice (1992: 119-126). United States Bureau of the Census (1975: 1077).

${ }_{25}$ Antonio Caño. «50ํaniversario de la muerte del expresidente.- Clinton...», El País, Madrid, 13-4-1995, p. 7.

${ }^{26}$ «Las elecciones presidenciales en los Estados Unidos.- El vencedor...», El Liberal, Madrid, 9-11-1932, p. 9.

27 «La elección presidencial yanqui... La prensa neoyorquina acoge favorablemente el triunfo del candidato demócrata... La prensa sudamericana acoge con satisfacción la elección de Roosevelt», Informaciones, Madrid, 9-11-1932, pp. 1 у 2. 
1933, transcurren cuatro meses durante los cuales se agrava la crisis en Norteamérica. Roosevelt jura su cargo cuando la depresión se encuentra en uno de sus momentos más críticos, como presenta el historiador liberal Arthur M. Schlesinger, Jr. (1995: 71): «Franklin D. Roosevelt became President when the Great Depression seemed to verify Karl Marx's prediction that capitalism would be destroyed by its own contradictions ${ }^{28}$.

El día 4 de marzo de 1933, Franklin D. Roosevelt, después de tomar posesión de su cargo en Washington D. C., pronuncia el discurso inaugural en el que presenta su programa y se reafirma en las promesas de un New Deal para Norteamérica. Es un discurso breve, claro y con un lenguaje sencillo y directo como era usual en él recogido fielmente por John G. Hunt ${ }^{29}$. En él comienza recalcando la difícil situación que se vive en los Estados Unidos en esos momentos, y que ha llegado el momento de decir la verdad, insistiendo en que el miedo es el peor enemigo:

I am certain that my fellow Americans expect that on my induction into the presidency I will address them with a candor and a decision which the present situation of our nation impels. This is pre-eminently the time to speak the truth, the whole truth, frankly and boldly. Nor need we shrink from honestly facing conditions in our country today. This great nation will endure as it has endured, will revive and will prosper. So, first of all, let me assert my firm belief that the only thing we have to fear is fear itself- nameless, unreasoning, unjustified terror which paralyzes needed efforts to convert retreat into advance (30).

También acusa a los que dirigen la Bolsa y a los cambistas sin escrúpulos de ser los principales causantes de los males de la economía: «the money changers have fled from their high seats in the temple of our civilitation. We may now restore that temple to the ancient truths. The measure of the restauration lies in the extent to which we apply social values more noble than mere monetary profit». A continuación, cita algunos aspectos que precisan intervención inmediata, como es reducir el nivel de paro entre los estadounidenses:

Our greatest primary task is to put people to work. This is no unsolvable problem if we face it wisely and courageously. It can be accomplished in part by direct recruiting by the government itself, treating the task as we would treat the emergency of a war, but at the same time, through this employment, accomplishing greatly needed projects to stimulate and reorganize the use of our natural resources (32).

Asimismo, Roosevelt hace hincapié en la necesidad de redistribuir el exceso de población en algunos sectores de la economía: «hand in hand with this we must frankly recognize the overbalance of population in our industrial centres and, by engaging on a nacional scale in a redistribution, endeavor to provide a better use of the land for those best fit-

${ }^{28}$ Igualmente, Frank Friedel (1987: 6) refleja ese momento: «when Roosevelt became president the nation was in the throes of an appalling crisis that had closed most of the banks». Asimismo, la prensa española lo recoge en sus titulares: «La toma de posesión del presidente Roosevelt coincide con una gravísima crisis financiera en los Estados Unidos», $A B C$, Madrid, 5-3-1933, pp. 35-36.

${ }^{29}$ Franklin D. Roosevelt. «First Inaugural Address, March 4, 1933». Cf. John G. Hunt (1995: 30-35). Este discurso es redactado por el propio presidente Roosevelt como escribe Richard Hofstadter (1959:351): «but this speech is really his own, the first draft was written in his own hand». 
ted for the land»e incrementar los precios de los productos del campo: «to raise the values of agricultural products and with this the power to purchase the output of the cities. It can be helped by preventing realistically the tragedy of the growing loss through foreclosure of our small homes and our farms». (32) Además, presenta un plan nacional que incluye todos los medios de transporte y comunicaciones y otros servicios de carácter público:

It can helped by nacional planning for and supervisión of all forms of transportation and of communications and other utilities which have a definitely public character. There are many ways in which it can be helped, but it can never be helped merely by talking about it. We must act and act quickly (32).

En materia de política exterior, el presidente electo defiende la buena vecindad:

In the field of world policy I would dedicate this nation to the policy of the Good Neighbor- the neighbor who resolutely respects himself and, because he does so, respects the rights of others- the neighbor who respects his obligations and respects the sanctity of his agreements in and with a world of neighbors» (33).

Pide a los norteamericanos disciplina y asegura que asumirá el mando para afrontar los problemas de la vida cotidiana:

We must move as a trained and loyal army willing to sacrifice for the good of a common discipline, because without such discipline no progress is made, no leadership becomes effective. We are, I know, ready and willing to submit our lives and property to such discipline, because it makes possible a leadership which aims at a larger good... I assume unhesitatingly the leadership of this great army of our people dedicated to a disciplined attack upon our common problems (34).

Finalmente, Roosevelt anuncia al país que se encuentra preparado para remediar la situación al amparo de la Constitución y con la colaboración del Congreso, si es posible, y, si no es así, pedirá al Congreso amplios poderes para actuar:

I am prepared under my constitutional duty to recommend the measures that a stricken nation in the midst of a striken world may require. These measures, or such other measures as the Congress may build out of its experience and wisdom, I shall see, within my constitutional authority, to bring to speedy adoption. But in the event that the Congress shall fail to take one of these two courses, and in the event that the national emergency is still critical, I shall not evade the clear course of duty that will then confront me. I shall ask the Congress for the one remaining instrument to meet the crisis- broad executive power to wage a war against the emergency, as great as the power that would be given to me if we were in fact invaded by a foreign foe (34).

El presidente Roosevelt en este discurso intenta infundir optimismo, destaca su intención de actuar rápidamente para solucionar la crisis y advierte que la nación pide acción. Así, introduce en el discurso la palabra action, en seis ocasiones: «This nation asks for action, and action now... through this program of action... action in this image... and need for undelayed action... they want direct, vigorous action» (30-35). 
En cuanto al mundo rural, en este acto inaugural el nuevo presidente demócrata anuncia tres importantes medidas dirigidas a mejorar el agro americano. La primera de ellas pretende: «to provide a better use of the land for those best fitted for the land» (32) expresando así una idea que no dejaría de hacer mella en el mundo rural abocado a reivindicaciones reformistas. La segunda va dirigida a subir el precio de los productos agrarios: «the task can be helped by definite efforts to raise the values of agricultural products and with this the power to purchase the output of our cities» (32). La tercera trata de evitar que los bancos acreedores tomen posesión de las granjas familiares por el impago de los plazos de sus hipotecas: «it can be helped by preventing realistically the tragedy of the growing loss, through foreclosure, of our small homes and our farms» (32). Esta iniciativa va a ser muy popular debido a que la pequeña propiedad rural está muy extendida en los Estados Unidos.

El discurso inaugural del presidente supone, así, una gran inyección de optimismo al país — como Patrick J. Maney (1992: 49) afirma: «for a nation rendered numb by the depression Roosevelt's inaugural provided a huge shot of adrenaline»— y acaba con estas significativas palabras:

We do not distrust the future of essential democracy. The people of the United States have not failed. In their need they have registered a mandate that they want direct, vigorous action. They have asked for discipline and direction under leadership. They have made me the present instrument of their wishes. In the spirit of the gift I take it. In this dedication of a nation we humbly ask the blessing of God. May He protect each of every one of us. May He guide me in the days to come (35).

\section{CONCLUSIONES}

Se puede concluir diciendo que la personalidad de Franklin D. Roosevelt es fundamental en la campaña electoral de 1932. Todos los historiadores coetáneos, así como la historiografía posterior destacan su gran facilidad para contactar con el ciudadano medio estadounidense, especialmente con ese «forgotten man» que sufría las consecuencias de la grave crisis económica. Es necesario destacar la fuerza de la oratoria que utiliza Roosevelt en todas sus apariciones públicas y especialmente en los discursos que pronuncia durante la campaña. El lenguaje que emplea es claro, sencillo y directo y va a ser una de sus principales bazas para llegar a los norteamericanos, facilitándole su camino hacia la nominación como candidato demócrata y, posteriormente, su llegada a la Casa Blanca. Se observa en toda la retórica empleada durante la campaña electoral una actitud de apoyo y defensa de la ideología liberal y democrática que él representa y que queda ampliamente reflejada en todos sus discursos. Asimismo, va a apelar a la necesidad de volver a los valores tradicionales para salir de la situación crítica que vive el país, y lo hace utilizando palabras con gran fuerza semántica como: acción, unidad, cambio, esfuerzo, trabajo, sacrificio, etc. Con su gran oratoria, el candidato demócrata sabe infundir confianza y esperanza a la población estadounidense.

El programa político que Franklin D. Roosevelt va a desarrollar en su New Deal ya había sido anunciado en sus discursos durante la campaña electoral y especialmente en su 
discurso inaugural, pronunciado en Washington, D. C., el día de su toma de posesión, el 4 de marzo de 1933. En él van a estar incluidas las principales líneas de acción de su primer mandato en la presidencia, 1933-1936, y especialmente de los cien primeros días en el cargo, en los que promueve quince medidas legislativas y durante los cuales, el pueblo americano, así como el Congreso, siguen a Roosevelt sin discusión y sin oponer ninguna resistencia a sus propuestas, como se recoge en las prensa española coetánea:

La iniciativa de todas las medidas para restablecer lo que se llama prosperidad en los Estados Unidos ha partido enteramente de Roosevelt. El Congreso no ha hecho más que aceptar lo que se le ha dado ya sazonado, cocido y puesto sobre la mesa por los técnicos que forman el Intelligence Trust... se ha recordado una vieja frase americana: «Cuanto menos Congreso, más Congreso»... «El Congreso ha durado más de tres meses; pero ha sido menos Congreso», en el sentido de no poner resistencia a la voluntad del Presidente ${ }^{30}$.

\section{BIBLIOGRAFÍA}

Bourne, Kenneth y WatT, D. Cameron, eds. (1986): British Documents on Foreign Affairs: Reports \& Papers from the Foreign Office Confidential Print. Part II (From the $1^{\text {st }}$ to the $2^{\text {nd }}$ World War). Series C, North America 1919-1939, Frederick, University Publications of America, Inc. Buhite, Russell D. y Levy, David W., eds. (1993): F.D.R.'s Fireside Chats, New York, Penguin Books.

BuRns, James. M. (1984): Roosevelt: The Lion and the Fox, New York, Harcourt Brace.

DizIKES, John (1979): Britain, Roosevelt and the New Deal: British Opinion, 1932-1938, New York, Garland Publishing, Inc.

FlynN, Edward J. (1947): You Are the Boss, New York, The Viking Press.

FreIDEL, Frank (1987): «Introduction: The Legacy of FDR», en FDR, the Man, the Myth, the Era, 1882-1945, editado por Rosenbaum, Herbert D. \& Bartelme, Elizabeth, New York, Greenwood Press, pp. 1-10.

FuSFEL, Daniel R. (1987): «The New Deal and the Corporate State» en FDR, the Man, the Myth, the Era, 1882-1945, editado por Rosenbaum, Herbert D. \& Bartelme, Elizabeth, New York, Greenwood Press, pp. 137-151.

Gosnell, Harold F. (1952): Champion Campaigner. Franklin D. Roosevelt, New York, The MacMillan Co.

Halasz, Nicholas (1961): Roosevelt through Foreign Eyes, New York, Van Nostrand Co.

HOFSTADTER, Richard et al. eds. (1959): Great Issues in American History. A Documentary Record, New York, Vintage Books, 2 vols.

Hunt, John G., ed. (1996): The Essential Franklin Delano Roosevelt, Avenel, Portland House.

KING, Judson (1959): The Conservation Fight. From Theodore Roosevelt to the TVA, Washington, D. C., Public Affairs Press.

Leuchtenburg, William E. (1963): Franklin D. Roosevelt and the New Deal, New York, Harper Torchbooks.

LeUChTENBURG, William E. (1983): In the Shadow of F. D. R.: from Harry Truman to Ronald Reagan, Ithaca\& London, Cornell University Press.

\footnotetext{
${ }^{30}$ José Pijoan. «Lo que pasa y pasará en los Estados Unidos.- El final de la luna de miel del Presidente y el Congreso», El Sol, Madrid, 15-8-1933, p. 1.
} 
MANEY, Patrick J. (1992): The Roosevelt Presence. The Life and Legacy of FDR, Berkeley, The University of California Press.

Moley, Raymond (1939): After Seven Years, New York, Harper \& Brothers Publishers.

NicE, David C. (1992): «Peak Presidential Approval from Franklin D. Roosevelt to Ronald Reagan», Presidential Studies Quarterly 22, (1992), pp. 119-126.

Peel, Roy V. y Donnelly, Thomas C. (1973): The 1932 Campaign. An Analysis, New York, Da Capo Press.

RobInson, Edgar E. (1970): They Voted for Roosevelt. The Presidential Vote, 1932-1944, New York, Octagon Books.

Roosevelt, Eleanor (1949): This I Remember, New York, Harper \& Row.

Roosevelt, Franklin D. (1932): Agriculture. What is Wrong? And What to Do about it? . F. D. Roosevelt's Speech at Topeka, Kansas, Sep. 14, 1932, New York City, The Democratic National Committee.

Roosevelt, Franklin D. (1939): Governor Roosevelt's Public Papers, Albany, (s.e.)

Rosenman, Samuel I. (1952): Working with Roosevelt, New York, Harper \& Brothers Publishers.

Rozwenc, Edwin C., ed. (1959): The New Deal. Revolution or Evolution?, Boston, D. C. Heath \& Co.

Ryan, Halford R. (1988): Franklin D. Roosevelt's Rhetorical Presidency, New York, Greenwood Press.

Savage, Sean J. (1991): The Party Leader, 1932-1945, Lexington, The University Press of Kentucky.

SCHLESINGER, Arthur M., Jr. (1957): The Age of Roosevelt. The Crisis of the Old Order, 1919-1933, Boston, Houghton Mifflin Co.

SCHLESINGER, Arthur M., Jr. (1974): «Foreword», en The Growth of Presidential Power: A Documentary History, editado por Goldsmith, William M., New York, Chelsea House, pp. i-xx.

SCHLESINGER, Arthur M., Jr. (1995): «Franklin D. Roosevelt Fifty Years After» en Remembering Franklin D. Roosevelt, 1882-1945. A Celebration of his Life and Legacy, editado por The Franklin \& E. Roosevelt Institute, New York, The Franklin \& E. Roosevelt Institute, p. 71.

SimPSON, Michael (1989): Franklin D. Roosevelt, Oxford \& New York, Basil Blackwell.

STEEL, Ronald (1980): Walter Lippmann and the American Century, Boston, Little Brown.

Tugwell, Rexford G. (1968): The Brain Trust, New York, The Viking Press.

U. S. BUREAU OF THE CENSUS (1975): Historical Statistics of the U. S., Colonial Times to 1975. Bicentennial Edition, Washington, D. C., U. S. Government Printing Office. 